\title{
KETERWAKILAN PEREMPUAN KADER PDI PERJUANGAN DALAM PEMILU LEGISLATIF 2019 DI DPRD DKI JAKARTA
}

\author{
Shinta Kartika Sari \\ Alumni Pasca Sarjana Ilmu Pemerintahan \\ Sekolah Tinggi Ilmu Pemerintahan Abdi Negara (STIP-AN), Jakarta \\ email:shintastipan@gmail.com
}

Paper Accepted: 21 Desember 2021 Paper Reviewed: 23-30 Desember 2021 Paper Edited: 01-06 Januari 2022 Paper Approved: 15 Januari 2022

\begin{abstract}
ABSTRAK
Representasi perempuan kader Partai Demokrasi Indonesia Perjuangan (PDI Perjuangan) dalam Pemilu Legislatif 2019 di Dewan Perwakilan Rakyat Daerah (DPRD) Provinsi DKI Jakarta, berdasarkan hasil penelitian perannya cukup signifikan menunjukkan representasi dari perempuan serta juga sudah memenuhi kuota 30\% keterwakilan perempuan dan sudah memenuhi persyaratan sesuai peraturan yang berlaku. Kualitas politik perempuan kader PDI Perjuangan dalam Pemilu Legislatif 2019 yang telah terpilih di DPRD Provinsi DKI Jakarta, sebagian besar telah paham terhadap yang menjadi tugas, pokok, dan fungsinya (tupoksi) sebagai wakil rakyat. Kualitasnya dapat dianggap sudah bagus dan terbukti bahwa sebelas orang kader PDI Perjuangan ini telah cukup aktif sebagai legislator di DPRD DKI Jakarta. Ini semua dapat terwujud karena memang proses kaderisasinya sudah sangat baik dan dapat dilaksanakan dengan baik oleh PDI Perjuangan.
\end{abstract}

Kata kunci: Keterwakilan Perempuan, DPRD DKI Jakarta, Pemilu Legislatif, PDI Perjuangan

\section{PENDAHULUAN}

\section{Latar Belakang}

Bangsa Indonesia sebagai bangsa yang menganut konsep demokrasi yang ditandai dengan adanya pemilihan umum (Pemilu) yang melibatkan masyarakat untuk memilih secara langsung, seperti pemilihan kepala negara, kepala daerah hingga pemilihan legislatif. Hal ini menunjukkan bahwa Indonesia merupakan negara yang berprogres pada masyarakat dalam menentukan pemimpin negara maupun daerah, sehingga memberikan warna baru untuk sistem politik di Indonesia.

Penyelenggaraan Pemilu sebagai salah satu kegiatan politik yang menjadi syarat bagi kehidupan negara yang demokratis. Pemilu merupakan salah satu mekanisme demokrasi untuk menentukan pergantian pemerintahan yang mana rakyat dapat terlibat dalam proses pemilihan wakil mereka di parlemen dan pemimpin nasional maupun daerah yang dilakukan secara langsung, umum, bebas, rahasia, jujur, adil, dan aman. Prinsip-prinsip ini sangat penting dalam proses pemilu sebagai indikator kualitas demokrasi (Ubaedillah A., 2015: 96).

Umumnya, yang berperan dalam Pemilu dan menjadi peserta Pemilu adalah partai politik. Dari sekian banyak partaipartai di Indonesia yang ikut dalam Pemilu, utamanya menarik untuk dikaji adalah PDI Perjuangan. Partai ini lahir 
sejak tahun 1999, yang diketuai oleh seorang tokoh perempuan, Megawati Soekarnoputri. PDI Perjuangan sebagai sebuah organisasi politik yang berfungsi nyata sebagai sarana rekruitmen politik. Dengan fungsinya ini diharapkan partai dapat menjalankan perekrutan anggota utamanya calon anggota legislatif (caleg) dengan baik. Ketika pemerintah mengharuskan setiap partai politik untuk mengikutsertakan Caleg Perempuan minimal 30\%, maka partai juga harus memenuhi kuota tersebut.

Berbagai upaya telah dilakukan PDI Perjuangan di antaranya melalui pengkoordinasian setiap tingkat kepengurusan untuk merekrut sebanyak mungkin caleg perempuan, kaderisasi anggota perempuan, sosialisasi tentang pentingnya keterlibatan perempuan dalam politik, pengembangan karir politik kader perempuan, merekrut caleg perempuan yang berkualitas dan mendampingi para caleg perempuan dalam melakukan proses kampanye, (Resta Konitiarani, 2017: 4555).

Perekrutan dalam partai politik sebagai proses yang mana individu atau kelompok-kelompok dilibatkan dalam peran politik aktif dan berkompetisi dalam pemilu. Perekrutan dilakukan partai politik tidak hanya melibatkan kandidat laki-laki tetapi juga melibatkan kandidat perempuan. Keikutsertaan perempuan dalam partai politik merupakan pemenuhan kuota $30 \%$ keterwakilan perempuan di parlemen. Namun, aturan kuota minimal 30\% bagi perempuan yang duduk di kursi legislatif hingga saat ini belum tercapai. Kuantitas yang belum memenuhi standar ini berdampak langsung pada kualitas keterlibatan perempuan sebagai pelaku pengambil kebijakan di ranah politik. Permasalahan ini, partai politik memiliki pengaruh besar dalam mewujudkan representasi perempuan di ranah politik.

Keterwakilan perempuan dalam kehidupan politik merupakan hal yang sangat penting dalam rangka mempengaruhi proses perumusan kebijakan yang memiliki dampak terhadap kehidupan perempuan dan peran perempuan dalam politik bukan sekadar mewakili kepentingan perempuan saja, melainkan juga perjuangan dalam rangka memenuhi hak perempuan dan menyetarakan derajat perempuan pada konteks konstruksi sosial dan politik. Ada beberapa hal perlunya representasi perempuan di suatu instansi publik apalagi yang menyangkut dengan pembuatan kebijakan seperti pada ranah legislatif ini. Perempuan diperlukan suaranya atau pendapatnya pada tahap formulasi atau penggodokan kebijakan utamanya yang menyangkut anak-anak dan perempuan itu sendiri. Sebagai contoh misalnya, pembuatan kebijakan terkait Kekerasan Dalam Rumah Tangga dan kejahatan terhadap anak, jika anggota legislatif perempuan cenderung banyak dalam segi kuantitas maka kebijakan yang diputuskan sesuai dengan apa yang diharapkan untuk melindungi perempuan dan anak.

Kehadiran perempuan dalam partai politik tentu memberikan efek yang cukup berbeda dalam dunia perpolitikan di tanah air, tetapi dalam menjalankan perannya di politik bahwa kaum perempuan mengalami beberapa hambatan di dalam menjalankan perannya. Secara umum terdapat tiga hambatan yang dialami kaum perempuan dalam menjalankan perannya yaitu hambatan kultur sosial masyarakat, hambatan psikologis, dan hambatan ekonomi (Yogi Maulana Malik, tanpa tahun: 1-10). Realitas ini secara tidak langsung telah merugikan perempuan, dilihat dari segi demokrasi, jumlah perempuan lebih dari setengah jumlah total penduduk; dari segi kesetaraan, keterwakilan dari perempuan untuk perempuan, sama halnya dengan tuntutan dari rakyat untuk rakyat; dan dari segi keterwakilan, banyak penelitian empris yang menunjukkan bila perempuan tidak terlibat dalam pengambilan keputusan, maka kepentingan mereka tidak dipertimbangkan secara sungguhsungguh.

Penelitian ini secara spesifik mengkaji keterwakilan perempuan kader PDI Perjuangan berdasarkan keterpilihan dalam Pemilu Legislatif Tahun 2019 di DPRD Provinsi DKI Jakarta. PDI 
Perjuangan merupakan sebuah partai politik, kehadirannya di parlemen ditunjukkan dengan tidak pernah absen untuk turut aktif dan berpartisipasi dalam setiap Pemilihan Umum Presiden, Kepala Daerah maupun di Lembaga Legislatif. Pada Pemilu Legislatif Tahun 2019 di Provinsi DKI Jakarta dengan perebutan kursi sebanyak 106 kursi, PDI Perjuangan berhasil memperoleh suara tertinggi dengan memperoleh 25 Kursi atau setara 23,58 persen, di susul oleh Gerindra 19 kursi, berikutnya PKS 16 kursi, Partai Demokrat 10 kursi, PAN 9 kursi, PSI 8 kursi, Nasdem 7 kursi, Golkar 6 kursi, PKB 5 kursi, dan PPP 1 kursi (republika.co.id).

Keterwakilan perempuan PDI Perjuangan di kursi legislatif DKI Jakarta pada periode 2019-2024 tercatat ada 11 politisi perempuan dari total 25 politisi PDI Perjuangan yang lolos ke Kebun Sirih tersebut. Jumlah tersebut telah melebihi syarat keterwakilan perempuan yang ditetapkan Komisi Pemilihan Umum (KPU) yaitu sebesar 30\% dengan total presentase sebesar 44 persen keterpilihan kader perempuan dari PDI Perjuangan.

Namun, ruang bagi perempuan di politik tidak hanya soal pemenuhan kuota melainkan juga benar-benar diharapkan menghadirkan kader perempuan yang berkualitas seperti memiliki kemampuan komunikasi politik dalam merepresentasikan perempuan. Dari sisi lain, mahalnya biaya politik dalam sistem demokrasi mengakibatkan, kalaupun perempuan bisa mendapat tiket sebagai caleg, tetapi mereka mengalami kesulitan untuk membiayai kampanye dan segala kebutuhan logistik pada saat pemilu. Realitas ini menyebabkan, yang banyak lolos dan menduduki jabatan sebagai legislator adalah perempuan dari kalangan menengah ke atas atau dari rumpun pejabat/elit politik dan hal lainnya (salah satu hambatan keterwakilan perempuan dilihat dari segi ekonomi).

Berdasarkan berbagai penelitian empiris bahwa para perempuan caleg maupun yang sudah menjadi anggota legislator, sekaligus kepala pemerintahan daerah, masih kurang mampu dan bisa memanfaatkan peran khalayak politik mereka yang perempuan. Selama ini khalayak perempuan hanya menjadi penonton (spectator) politik, sehingga keterlibatan aktif suara mereka tidak mampu diraih. Keterlibatan perempuan dalam hal jumlah dan kuantitas saja yang diperjuangkan. Tetapi, isu-isu serius perempuan seperti kesejahteraan perempuan, jaminan kesehatan, kehidupan perempuan, pekerja perempuan dan masih banyak hal malah kurang digunakan sebagai amunisi menawarkan visi politik untuk dibawa ke ranah publik yang lebih besar bagi perjuangan kesetaraan dan keadilan gender bagi kaum perempuan di tanah air (Henry Subiakto dan Rachmah Ida, 2012: 161).

Sekali lagi, memang ada cukup banyak hambatan yang membuat perempuan terkesan lebih rendah dalam berkomunikasi, apalagi komunikasi politik, dibandingkan dengan laki-laki. Hambatan pertama adalah hambatan kultural atau sosial budaya. Secara kultural, perempuan diidentikkan sebagai orang yang pemalu, takut, dan suka menangis. Sedangkan laki-laki identik dengan berani, pantang menyerah, dan tidak pernah menangis. Inilah yang menyebabkan perempuan mempunyai kendala dalam melakukan komunikasi politik karena perempuan sering minder, tak punya keberanian dan rendah diri ketika mendapatkan kritikan.

Hambatan kultural lain, perempuan juga diidentikkan sebagai ibu rumah tangga, pekerja domestik, dan tak pantas tampil di publik dibandingkan laki-laki. Inilah yang menyebabkan perempuan mendapatkan banyak kritik ketika tampil di muka publik. Perempuan juga dianggap sebagai orang yang tak pantas memimpin. Identitas inilah yang menyebabkan perempuan menjadi enggan untuk berbicara terbuka, malu, dan tidak percaya diri (jurnalperempuan.org).

Hambatan kedua adalah adanya hambatan pengetahuan. Banyak perempuan yang tidak punya waktu untuk pergi dari rumah karena ia bertanggungjawab secara domestik. Perempuan yang bekerja di luar juga tak banyak memunyai akses untuk 
berkomunikasi, berjaringan, dan mencari pengetahuan karena ia juga harus mengurusi urusan domestik. Inilah yang menyebabkan laki-laki mempunyai banyak pengetahuan dan banyak waktu untuk berjaringan. Dalam berkomunikasi secara politik, ini menyebabkan perempuan menjadi minder ketika melakukan kampanye politik karena menganggap politik adalah dunianya laki-laki saja (joglosemar.co).

Asumsi-asumsi yang ada pada persepsi di atas yaitu, perempuan memiliki cara pandang yang berbeda dengan lakilaki, hal ini disebabkan oleh perbedaan pengalaman dan aktivitas antara laki-laki dan perempuan. Karena dominasi politik yang dimiliki oleh laki-laki menyebabkan keterbatasan perempuan dalam mengekspresikan dirinya. Agar dapat berpartisipasi dalam masyarakat maka perempuan harus mentransformasi cara mereka menjadi cara-cara yang dapat diterima oleh laki-laki, (Richard West dan Lynn Turner, 2007: 520). Berdasarkan beberapa fakta di atas, tentu saja ini berkaitan dengan kualitas keterwakilan perempuan kader PDI Perjuangan dalam Pemilu Legislatif 2019 di DPRD Provinsi DKI Jakarta, yang bukan saja pemenuhan kuota keterwakilan perempuan melainkan di dukung dengan kualitas politiknya, sehingga tujuan dari keterwakilan perempuan tercapai sesuai kepentingan dan ideologi PDI Perjuangan yang menjelaskan berperan dalam mendidik dan menuntun rakyat untuk membangun kesadaran politik dan mengolah semua tenaga rakyat dalam satu gerakan politik untuk mencapai kemerdekaan politik, ekonomi, mewujudkan kesejahteraan dan berkeadilan sosial. Hal ini semakin menarik untuk dikaji, sebab PDI Perjuangan merupakan salah satu partai nasionalis di Indonesia, yang dipimpin oleh seorang perempuan.

\section{Perumusan Masalah}

1. Bagaimana representasi perempuan kader PDI Perjuangan dalam Pemilu Legislatif 2019 di DPRD Provinsi DKI Jakarta?
2. Bagaimana kualitas politik perempuan kader PDI Perjuangan dalam Pemilu Legislatif 2019 di DPRD Provinsi DKI Jakarta?

3. Upaya apa yang dilakukan PDI Perjuangan dalam meminimalisirkan hambatan-hambatan untuk merealisasikan keterwakilan perempuan dalam Pemilu Legislatif 2019?

\section{Maksud dan Tujuan Penelitian}

1. Untuk Menganalisis representasi perempuan kader PDI Perjuangan dalam Pemilu Legislatif 2019 di DPRD Provinsi DKI Jakarta.

2. Untuk memperoleh informasi secara terperinci kualitas politik keterwakilan perempuan kader PDI Perjuangan di Pemilu Legislatif 2019 Provinsi DKI Jakarta.

3. Mendeskripsikan upaya yang dilakukan PDI Perjuangan dalam meminimalisirkan hambatanhambatan untuk merealisasikan keterwakilan perempuan dalam Pemilu Legislatif 2019.

\section{Waktu dan Tempat Penelitian}

Bahan penelitian (obyek penelitian) adalah lembaga DPRD (Provinsi), dengan unit analisisnya adalah mengenai keterwakilan perempuan kader PDI Perjuangan utamanya adalah legislator perempuan terpilih di Pemilu Legislatif 2019. Berdasarkan obyek penelitian ini juga menjelaskan bahwa waktu dan tempat penelitian adalah Kantor DPRD DKI Jakarta, dengan alasan dari pemilihan lokasi ini sebab yang dikaji adalah representasi perempuan dari kader PDI Perjuangan atau perempuan dari Fraksi PDI Perjuangan yang mengemban amanat rakyat sebagai legislator di Kebun Sirih (Gedung DPRD DKI Jakarta). Pemahaman tentang obyek penelitian dan unit analisis, serta lokasi penelitian ini, mempermudah penulis dalam melakukan proses pengumpulan data, proses analisis data hingga menarik kesimpulan untuk menjawab rumusan permasalahan penelitian yang diajukan dalam penelitian ini. 


\section{METODE PENELITIAN}

Desain penelitian merupakan kerangka prosedur kerja yang akan dilakukan pada waktu penelitian dikerjakan oleh penulis. Dengan adanya desain penelitian memudahkan peneliti untuk dapat berada secara langsung dengan cara mengamati, menganalisis, mencatat dan menggambarkan permasalahan dengan apa adanya sesuai dengan kondisi lapangan dari penelitian tersebut. Desain penelitian yang dirancang dalam penelitian ini menggunakan desain penelitian kualitatif. Pilihan desain kualitatif untuk lebih banyak mengeksplorasi perilaku objek, hal mana berupa kasus tunggal dari keterwakilan perempuan kader PDI Perjuangan dalam Pemilu Legislatif 2019 di DPRD Provinsi DKI Jakarta.

Pendekatan kualitatif juga dijelaskan bahwa, suatu proses yang digunakan untuk mengumpulkan dan menganalisa informasi untuk meningkatkan pemahaman kita pada suatu topik (Imam Gunawan, 2013: 79). Penelitian kualitatif bertujuan untuk mengumpulkan informasi aktual secara rinci dan melukiskan realita yang ada (Jalaludin Rakhmat, 2000: 25). Dalam penelitian ini, penulis menggunakan teknik pengumpulan data dengan metode wawancara dengan perincian adalah anggota/pengurus PDI Perjuangan sekaligus anggota DPRD PDI Perjuangan DKI Jakarta dan juga dari akademisi politik (pengamat politik) yang memahami mengenai PDI Perjuangan. Sehingga demikian, berdasarkan desain penelitian yang dilakukan akan dapat memperoleh gambaran legislator terpilih dari kader PDI Perjuangan sebagai representasi perempuan di DPRD DKI Jakarta.

\section{HASIL PENELITIAN DAN PEMBAHASAN}

\section{Keterwakilan Perempuan}

Periode pasca Orde Baru dilakukan upaya berbagai prakarsa perubahan yang berupaya untuk memastikan partisipasi masyarakat dan pengikutsertaan suara mereka dalam tata pemerintahan. Untuk memperbaiki ketidakseimbangan gender di lembaga legislatif tingkat nasional, subnasional dan lokal, sebuah kuota yang tidak wajib sifatnya diperkenalkan melalui Undang-Undang Nomor 12 Tahun 2003 Keterwakilan Perempuan di Indonesia utamanya di parlemen. Ketentuan ini masih dilanjutkan berdasarkan UndangUndang Nomor 7 Tahun 2017, misal, Pasal 245 menyatakan bahwa "Daftar bakal calon sebagaimana dimaksud dalam Pasal 243 memuat keterwakilan perempuan paling sedikit 30\% (tiga puluh persen)."

Pemberian Kuota 30\% kepada perempuan didasari oleh penafsiran dari Huntington dan Nelson bahwa "partisipasi politik perempuan di negaranegara berkembang cenderung rendah jika dibandingkan dengan laki-laki, karena perempuan lebih terlibat dalam urusan rumah tangga daripada urusan politik" (Huntington dan Nelson, 1990: 23).

Berdasarkan asumsi tersebut maka Indonesia mengedepankan perempuan dalam berpolitik di parlemen melalui pemberian kuota 30\% perempuan. Kuota ini tentunya menyasar jumlah (kehadiran). Pemberian kuota ini lebih mengacu terhadap teori representasi yakni tepatnya representasi deskriptif. Yang dimaksud representasi deskriptif adalah sebuah bentuk keterwakilan yang berdasarkan persamaan dan kemiripan antara wakil dan yang diwakili (konstituen/pemilih). Dalam representasi ini, maka wakil menghadirkan sesuatu yang absen dengan mengangkat kemiripan atau mencerminkan kesamaan, dan dalam bertindak ia mengatasnamakan yang diwalikinya, (Nuri Suseno, 2014: 115).

Representasi politik perempuan merupakan satu elemen penting, jika kita ingin menempatkan konteks demokratisasi Indonesia dalam perspektif demokrasi yang ramah gender (gender democracy). Berbeda dengan para politisi laki-laki yang lebih asyik dengan "narasinarasi politik besar," sedangkan kalangan aktivis perempuan tampaknya lebih fokus dan konsisten untuk memperjuangkan kuota 30\% representasi politik perempuan sebagai agenda perjuangan bersama, (Anis Maryuni Ardi, 2014: 306). 
Jika merujuk kepada perundangundangan yang digunakan dalam Pemilu Legislatif 2019 yakni Undang-Undang Nomor 7 Tahun 2017 tentang Pemilihan Umum, bahwa terdapat enam pasal yang mengatur mengenai 30\% (Tiga Puluh Persen) keterwakilan perempuan dalam pemilu. Pasal-pasal tersebut adalah:

1. Pasal 173 ayat (2) huruf e, berbunyi: menyertakan sekurang-kurangnya $30 \%$ (tiga puluh persen) keterwakilan perempuan pada kepengurusan partai politik tingkat pusat;

2. Pasal 177 huruf d, berbunyi: surat keterangan dari pengurus pusat partai politik tentang penyertaan keterwakilan perempuan sekurangkurangnya 30\% (tiga puluh persen) sesuai dengan ketentuan peraturan perundang-undangan;

3. Pasal 245, berbunyi: daftar bakal calon sebagaimana dimaksud dalam Pasal 243 memuat paling sedikit 30\% (tiga puluh persen) keterwakilan perempuan.

4. Pasal 246 ayat (2), berbunyi: di dalam daftar bakal calon sebagaimana dimaksud pada ayat (1), setiap 3 (tiga) orang bakal calon terdapat sekurangkurangnya 1 (satu) orang perempuan bakal calon;

5. Pasal 248 ayat (1), (2), dan (3) berbunyi:

(1) KPU melakukan verifikasi terhadap kelengkapan dan kebenaran dokumen persyaratan administrasi bakal calon anggota Dewan Perwakilan Rakyat dan verifikasi terhadap terpenuhinya jumlah sekurang-kurangnya 30\% (tiga puluh persen) keterwakilan perempuan.

(2) KPU Provinsi melakukan verifikasi terhadap kelengkapan dan kebenaran dokumen persyaratan administrasi bakal calon anggota Dewan Perwakilan Rakyat Daerah Provinsi dan verifikasi terhadap terpenuhinya jumlah bakal calon sekurangkurangnya $30 \%$ (tiga puluh persen) keterwakilan perempuan.
(3) KPU Kabupaten/Kota melakukan verifikasi terhadap kelengkapan dan kebenaran dokumen persyaratan administrasi bakal calon anggota Dewan Perwakilan Rakyat Daerah Kabupaten/Kota dan verifikasi terhadap terpenuhinya jumlah bakal calon sekurangkurangnya 30\% (tiga puluh persen) keterwakilan perempuan.

6. Pasal 249 ayat (2), berbunyi: dalam hal daftar bakal calon tidak memuat keterwakilan perempuan paling sedikit $30 \%$ (tiga puluh persen), KPU, KPU Provinsi, dan KPU Kabupaten/Kota memberikan kesempatan kepada partai politik untuk memperbaiki daftar bakal calon tersebut.

Meskipun telah ada peraturan perundangan yang memandatkan kuota $30 \%$ dalam parlemen, tidak serta-merta menjamin peningkatan keterwakilan perempuan dalam politik. Selain itu, dalam kenyataannya, pemenuhan kuota tersebut bukanlah suatu hal yang mudah. Meskipun ketentuan yang ada sifatnya mensyaratkan, itu hanya disertai sanksi moral dan bukan sanksi yang tegas yang dapat mendesak pemenuhan kuota itu. Walaupun ada peluang bagi perempuan untuk berkiprah di bidang politik, khususnya menjadi caleg, tetapi tetap saja kesempatan tersebut bergantung pada kepemimpinan partai politik, hal mana peran partai politik sangat penting dalam menentukan apakah perempuan bisa duduk di lembaga legislatif, (Muhammad Zamroni, 2013: 125).

Padahal, jika berbagai peraturan pelaksanaan kebijakan afirmasi perempuan membawakan hasil 30\% keterwakilan perempuan di parlemen tercapai, maka ada harapan keterwakilan deskriptif bisa memunculkan keterwakilan substantif perempuan dalam politik. Sebab, kebijakan kuota yang merupakan sebagai gagasan dari affirmative action, pada dasarnya sebagai "langkah strategis" untuk mengupayakan kemajuan dalam hal kesetaraan dan kesempatan yang lebih bersifat substantif dan bukannya 
formalitas, utamanya untuk kaum perempuan, (Ani Widyani Soetjipto, 2005: 179).

Maksud dari keterwakilan atau pemaknaan representasi substantif merupakan konsep keterwakilan yang menunjukkan bahwa kegiatan yang dilakukan oleh seorang wakil adalah untuk kepentingan yang diwakilinya. Maksudnya bahwa pengertian keterwakilan substantif adalah para anggota legislatif akan lebih bisa menyuarakan isu-isu perempuan, anak, pendidikan, kesejahteraan sosial, dan lingkungan. Selain itu, peraturan perundang-undangan yang terkait isu-isu perempuan akan banyak dihasilkan, Nuri Suseno, 2014: 115-116).

Namun realitasnya, para perempuan yang berada di partai politik dan dinominasikan sebagai caleg oleh partainya menyebutkan hambatan yang mereka rasakan antara lain adalah kriteria sangat maskulin yang diterapkan, tidak ada kriteria yang memasukkan kerja khas perempuan, yang artinya kekuasaan dominan ada di tangan laki-laki yang lebih diutamakan untuk menjadi anggota legislatif, yang mana perempuan biasanya hanya di jadikan sebagai pelengkap persyaratan dan sekadar memenuhi undang-undang (sistem kuota 30\% tersebut). Tidak banyak partai politik yang benar-benar mengusung perempuan dengan menempatkan perempuan pada caleg nomor urut satu, (Muhammad Zamroni, 2015: 125-126).

Dengan demikian, keterwakilan perempuan bukan saja berbicara kuota namun kualitas politik, bukan menjadi penonton namun pemain dalam ranah penentu kebijakan, sehingga tujuan dari keterwakilan perempuan tersebut tercapai sesuai ideologi partai untuk kepentingan rakyat.

\section{Representasi Kader Perempuan PDI Perjuangan di DPRD DKI Jakarta}

Pasca Pemilu Legislatif 2019 caleg terpilih menjalankan pelantikan sebagai anggota legislator DPRD DKI Jakarta yang dilaksanakan pada 26 Agustus 2019. Jumlah anggota DPRD DKI Jakarta yang dilantik untuk periode 2019-2024 sebanyak 106 orang yang berasal dari 10 partai, di antaranya 16 orang sudah menjabat diperiode sebelumnya. Jumlah anggota DPRD DKI Jakarta berdasarkan partai dengan komposisinya sebagai berikut: PDIP 25 kursi, Partai Gerindra 19 kursi, PKS 16 kursi, Partai Demokrat 10 kursi, PAN 9 kursi, PSI 8 kursi, Partai Nasdem 7 kursi, Partai Golkar 6 kursi, PKB 5 kursi, dan PPP 1 kursi. Jumlah anggota paling banyak berasal dari PDI Perjuangan sebanyak 25 orang, dan yang paling sedikit PPP 1 orang, anggota yang berasal dari PSI ada 8 orang meskipun partai baru tetapi jumlah ini cukup banyak dibandingkan partai-partai lama seperti PKB, PPP, Golkar dan Nasdem. Jumlah anggota berdasarkan persentase jenis kelamin laki-laki sebesar 84 legislator (79 persen) dan perempuan sebanyak 22 legislator (21 persen) (statistik.jakarta.go.id).

Berdasarkan rincian data ini sebenarnya angka keterwakilan perempuan di parlemen Indonesia masih di bawah rata-rata global. Jika di global itu 24 persen, kita yang di atas 20 persen itu baru di tingkat DPR, yaitu 20,5 persen. Di DPRD provinsi dan DPRD kabupaten/kota secara keseluruhan, bahkan di bawah 20 persen (nasional.sindonews.com). Namun, jika melihat data secara reprsentatif deksriptif berdasarkan lokasi penelitian yakni DKI Jakarta, maka representasi perempuan dari kader PDI Perjuangan yang terpilih di DPRD DKI Jakarta adalah sebesar 11 anggota (44 persen), pencapaian ini melebihi keterwakilan perempuan yang ditetapkan oleh KPU sebesar 30\%. Hasil ini juga menjadi lebih menarik, jika dilihat bahwa representasi perempuan mengalami peningkatan dari 9 perempuan legislator terpilih menjadi 11 anggota DPRD PDI Perjuangan berdasarkan hasil Pemilu Legislatif 2014 lalu, namun hitungan terakhir ini tidak merujuk atas total jumlah anggota DPRD PDI Perjuangan yang terpilih, sebab jika merujuk total jumlah anggota legislator DPRD PDI Perjuangan terpilih mengalami penurunan anggota DPRD terpilih sebesar 3 orang yakni dari 28 orang menjadi 25 orang (Hasil Wawancara, Efriza, Akademisi). 
Berdasarkan rincian anggota DPRD terpilih menunjukkan representasi perempuan sangat baik dan tinggi sebab dari 25 orang kader PDI Perjuangan sebagai anggota DPRD yang terpilih, terdapat 11 orang perempuan sebagai legislator terpilih, rincian ini juga menunjukkan sudah memenuhi kuota $30 \%$ dan sudah memenuhi peraturan yang berlaku (Wawancara, Wa Ode Herlina dan Agustina Hermanto, Anggota DPRD). Keterpilihan anggota legislator ini juga menunjukkan peran perempuan di dalam berpartisipasi sebagai kekuatan suara kepada partai itu cukup berarti sekali (Wawancara, Merry Hotma, Anggota DPRD DKI Jakarta).

Keberhasilan representasi perempuan kader PDI Perjuangan tak hanya di DPRD DKI Jakarta semata, tetapi representasi ini juga telah dijalankan di struktur PDI Perjuangan dengan realitas adanya keterwakilan perempuan di setiap jajaran pengurus, kemudian ada pengangkatan DPC Perempuan, ketentuan ini dijalankan karena memang PDI Perjuangan memang mewajibkan $30 \%$ keterwakilan perempuan dalam kepengurusan tingkat partai (Wawancara, Wa Ode Herlina, Anggota DPRD/Ketua DPC PDI Perjuangan Jakarta Pusat).

\section{Kualitas Kader PDI Perjuangan sebagai Representasi Perempuan \\ DPRD DKI Jakarta (DPRD} Provinsi) adalah lembaga perwakilan rakyat daerah yang berkedudukan sebagai unsur penyelenggara pemerintah daerah provinsi. DKI Jakarta hanya memiliki satu lembaga perwakilan yaitu DPRD Provinsi DKI Jakarta didasari alasan kekhususan Provinsi DKI Jakarta yang dianggap sebagai daerah otonom yang diletakkan pada tingkat provinsi (hukumonline.com). DPRD provinsi terdiri atas anggota partai politik peserta pemilihan umum yang dipilih melalui pemilu. DPRD Provinsi mempunyai tiga fungsi yakni, fungsi legislasi, fungsi anggaran dan fungsi pengawasan yang dijalankan dalam kerangka representasi rakyat di tingkat provinsi. Kedudukan dan keberadaan lembaga perwakilan rakyat daerah mengandung arti penting dalam memperhatikan kepentingan rakyat yang dirumuskan dalam suatu kebijakan pemerintah daerah, sehingga diharapkan timbulnya keterpaduan antara kebijakan yang dirumuskan dengan partisipasi masyarakat aktif dan bertanggungjawab.

Pemahaman terhadap representasi legislator perempuan terkait kinerja dapat dinyatakan bahwa keterwakilan perempuan sebagai anggota DPRD DKI Jakarta dari fraksi PDI Perjuangan, sebagian besar telah paham mengenai apa yang menjadi tugas, pokok dan fungsi (topoksi) sebagai wakil rakyat (Wawancara, Merry Hotma).

Dalam mencapai kualitas politik perempuan sebagai legislator DPRD DKI Jakarta dalam Pemilu Legislatif 2019, bagi Agustina Hermanto yang merupakan anggota DPRD DKI Jakarta yang terpilih kali pertama mengakui bahwa kader-kader PDI Perjuangan memiliki kesempatan yang terbuka, namun ada persyaratan kualitifikasi yang dilakukan untuk menjadi wakil rakyat, sehingga ketika terpilih sesuai dan berkualitas melayani rakyat (Wawancara, Agustina Hermanto). Wajar akhirnya, menurut Wa Ode Herlina yang merupakan anggota DPRD DKI Jakarta PDI Perjuangan bahwa kualitas legislator perempuan PDI Perjuangan bagus dan terbukti, bahkan 11 orang keterwakilan perempuan kader PDI Perjuangan ini cukup aktif. Ini terjadi karena memang proses kaderisasinya sangat baik dan terlaksana, maksudnya kita diberikan kesempatan untuk menambah pengetahuan. Artinya, kader PDI Perjuangan diberikan kesempatan untuk belajar, menambah kapasitas, menambah literatur, agar sebagai kader perempuan di PDI Perjuangan lebih memahami tupoksinya dan diberikan kesempatan yang sama dan tidak dibatasi, (Wawancara Wa Ode Herlina).

Meminimalisir Hambatan dalam
Mewujudkan Representasi Perempuan
PDI Perjuangan merupakan salah
satu kekuatan politik besar yang ada di
Indonesia. Dalam lima kali Pemilu pasca
Orde Baru yang digelar pada tahun 1999, 
2004, 2009, 2014, dan 2019 menunjukkan partai ini memiliki basis massa dan dukungan yang kuat. Besarnya dukungan ini tercermin dengan perolehan suara yang cukup tinggi pasca pemilu Orde Baru.

Besarnya kekuatan partai berlambang banteng moncong putih ini tak lepas dari pesona kharismatik yang dimiliki salah satu putri Bung Karno yang juga menjabat sebagai Ketua Umum PDI Perjuangan yakni Megawati Soekarnoputri. Personifikasi dirinya sebagai ruh PDI Perjuangan merupakan harga mati yang tidak bisa ditawar. Akibatnya, Megawati menjadi penentu sentral dalam setiap kebijakan dan keputusan partai. Bahkan, segala keputusan politik yang dikeluarkan oleh partai di setiap tingkatan harus memperoleh persetujuannya dan setiap kader wajib mengamankan rekomendasi yang diputuskannya selaku Ketua Umum.

Dalam upaya mewujudkan cita-cita nasional, PDI Perjuangan menganut prinsip demokrasi yang menempatkan Kepemimpinan Pusat Partai sebagai sentral gerakan; suatu kepemimpinan yang dipimpin ideologi Pancasila 1 Juni 1945; kepemimpinan yang mengandung manajemen satu arah dan satu tujuan yaitu masyarakat adil dan makmur, dan suatu kepemimpinan yang sesuai dengan kepribadian bangsa yaitu gotong royong.

Ketua Umum memiliki hak prerogatif untuk menentukan demokrasi di dalam partai, yang membatasi dirinya sendiri dengan batas berupa kepentingan rakyat yang sesuai dengan amanat Pancasila 1 Juni 1945 dan Undang-Undang Dasar Negara Republik Indonesia Tahun 1945. Inilah yang menjadi pembeda dalam konsep demokrasi yang dianut oleh PDI Perjuangan dengan konsep demokrasi berdasarkan faham liberalisme atau fasisme maupun dengan partai-partai lainnya (pdiperjuangan.id).

PDI Perjuangan menetapkan diri untuk berada dalam satu gerbong perjuangan bersama rakyat sebab ini adalah tanggung jawab sejarah yang tidak boleh dihilangkan. Sehingga, setiap kader dituntut memahami rakyat, menghimpun semangat, mengkonsolidasi kemauan, mengorganisir tindakan rakyat, mendidik dan menuntut rakyat untuk membangun kesadaran politik, menanamkan keyakinan atas kemampuan rakyat, mengolah semua tenaga rakyat dalam satu gerak politik, menggerakkan rakyat untuk berjuang bersama, dan mengawal kerja politik ideologis yang membumi (pdiperjuangan.id).

Pemahaman akan ideologi partai ini ternyata tak menjadi kendala bagi kaderkader perempuan PDI Perjuangan. Merry Hotma menyatakan, ia tidak begitu ada kendala, karena saya cepat belajar dan menyesesuaikan diri, sebagai wakil rakyat harus paham apa yang menjadi tupoksi (tugas, pokok, dan fungsi) kita (Wawancara, Merry Hotma). Fraksi PDI perjuangan itu cukup solid, kesolidan ini memudahkan dalam memperjuangan program-program kepartaian, meskipun tentu saja ada hambatan yang dialami sebagai wakil rakyat. Namun, harus dihadapi dan mencari solusinya, dengan merujuk kepada keputusan dan kesolidan partai serta pendekatan antar fraksi lain jika diperlukan dalam memperjuangkan program-program kepartaian untuk masyarakat (Wawancara, Wa Ode Herlina).

PDI Perjuangan juga telah banyak melakukan upaya untuk meminimalisirkan hambatan-hambatan dalam merealisasikan keterwakilan perempuan, yaitu: pertama, partai sudah melakukan kaderisasi khusus dari keterwakilan perempuan; kedua, dalam struktur kepartaian adanya bidang perempuan dan anak; dan ketiga, adanya pelatihan keahlian untuk perempuan dan juga kursus-kursus kader keterwakilan perempuan (Wawancara Wa Ode Herlina).

Anggota legislator dari Kader PDI Perjuangan juga memahami meminimalisir upaya untuk melakukan representasi dari perempuan dan juga sekaligus masyarakat. Legislator Herry Hotma menyatakan,

"dalam meperjuangkan kepentingan masyarakat, untuk meminimalisir kegagalan, saya melakukan pendekatan dan komunikasi dengan rekan anggota DPRD dari fraksi yang sama maupun fraksi lain yang memiliki tujuan yang sama demi kepentingan masyarakat." 
Langkah yang dilakukan oleh PDI Perjuangan untuk melakukan upaya meminimalisirkan hambatan-hambatan untuk merealisasikan keterwakilan perempuan juga diungkapkan Agustina Hermanto, sebagai berikut: pertama, meminta kader-kadernya untuk mengikuti aturan yang ada di partai; keda, dalam melakukan perekrutan caleg dalam Pemilihan Legislatif 2019 itu sudah jelas bahwa memang Perempuan harus diikutkan minimal 30\% dan memang juga kader-kader perempuannya juga terinfokan serta teredukasi untuk berpartisipasi dalam Pemilihan Legislatif lalu; dan ketiga, mengedukasi para kader mau ikut dalam pemilihan legislatif sebagai calon legislatif, (Wawancara, Agustina Hermanto).

Namun, persoalan yang terus menyelimuti keterwakilan perempuan secara keseluruhan di lembaga parlemen, dalam upaya menuju keseimbangan gender, diperlukan dukungan dengan melakukan konsolidasi dan strategi dalam berbagi peran yang sulit, jika tidak maka kita akan kesulitan. Di samping itu, juga diperlukan soal komitmen bagaimana kita mendukung penguatan keterwakilan perempuan di parlemen. Bahwa ini agenda yang merupakan sebuah keniscayaan dan keharusan dalam pengawalan demokrasi elektoral. Tapi kita juga punya tantangan konsolidasi yang harus dikonkretkan, (sindonews.com).

\section{KESIMPULAN}

Representasi perempuan kader PDI Perjuangan dalam pemilu legislatif 2019 di DPRD Provinsi DKI Jakarta, sesuai hasil penelitian ditarik kesimpulan bahwa Representasi keterwakilan perempuan PDI Perjuangan di caleg (pemilu) 2019 itu cukup signifikan dan tercapai terlihat dari jumlah caleg perempuan yang menjadi anggota dewan. Jadi fraksi PDI Perjuangan sebagai bagian dari anggota DPRD tahun 2019 memperoleh sebanyak 25 kursi, hal mana ada 11 orang keterwakilan perempuan sebagai anggota DPRD DKI Jakarta, sehingga demikian dapat dikatakan bahwa PDI Perjuangan sudah memenuhi kuota 30\% dalam pencalegan, bahkan keterpilihan sudah melampaui peraturan yang berlaku.

Kualitas politik perempuan kader PDI Perjuangan dalam Pemilu Legislatif 2019 di DPRD Provinsi DKI Jakarta, sesuai hasil penelitian dapat ditarik kesimpulan bahwa Keterwakilan perempuan sebagai anggota DPRD DKI Jakarta dari fraksi PDI Perjuangan, sebagian besar paham mengenai apa yang menjadi tupoksinya sebagai wakil rakyat. Kualitasnya dapat dikatakan sudah bagus dan terbukti seperti 11 orang keterwakilan perempuan kader PDI Perjuangan ini cukup aktif dalam menjalankan kinerjanya sebagai legislator.

Ini terjadi karena memang proses kaderisasi di PDI Perjuangan telah berjalan sangat baik, maksudnya kaderkader PDI Perjuangan ini diberikan kesempatan untuk menambah pengetahuan dalam proses memahami kinerjanya sebagai legislator melalui diberikan kesempatan untuk belajar, menambah kapasitas, menambah literatur, agar sebagai kader perempuan di PDI Perjuangan lebih memahami tupoksi dan diberikan kesempatan yang sama dan tidak dibatasi dalam menjalankan perannya sebagai legislator.

Upaya yang telah dilakukan PDI Perjuangan dalam meminimalisirkan hambatan-hambatan untuk merealisasikan keterwakilan perempuan dalam Pemilu Legislatif 2019 lalu, sebagai berikut: pertama, telah melakukan kaderisasi khusus keterwakilan perempuan; kedua, dalam struktur kepartaian telah mengedepankan adanya keterwakilan perempuan di setiap jajaran pengurus, kemudian ada pengangkatan DPC Perempuan, berbagai ketentuan ini dapat dijalankan karena memang PDI Perjuangan telah mewajibkan 30\% keterwakilan perempuan dalam kepengurusan tingkat partai; dan juga telah adanya bidang perempuan dan anak; ketiga, adanya pelatihan keahlian untuk perempuan dan juga adanya kursus-kursus kader keterwakilan perempuan; dan keempat, adanya upaya mengedukasi para kader agar mau ikut dalam pemilihan legislatif sebagai calon legislatif. 
Meski begitu, berdasarkan kesimpulan yang dipaparkan diatas, penulis memberikan beberapa saran yakni kualitas keterwakilan perempuan sebagai anggota DPRD perlu terus dioptimalkan lagi, di samping itu, bagi para stakeholders atau pelaksana kebijakan harus lebih mengupayakan pendidikan politik melalui program pemberdayaan perempuan agar representasi perempuan terus meningkat. Tuntutan untuk meningkatkan jumlah keterwakilan perempuan juga harus diimbangi dengan upaya untuk menjamin bahwa perempuan yang akan menjadi wakil rakyat harus benar-benar berkualitas, memahami kepentingan perempuan serta mampu memperjuangkan dan mewujudkannya dalam dinamika politik di parlemen.

\section{DAFTAR PUSTAKA}

Anis Maryuni Ardi, Perempuan Di Legislatif: Advokasi Perempuan Legislatif Bagi Kepentingan Dapil Di Dewan Perwakilan Rakyat Daerah Jawa Timur, Jurnal Politik Muda, Vol. 3 No. 3, Agustus-Desember 2014, hal.306, sumber http://journal.unair.ac.id/downloadfullpapers-ipma2df691556full.pdf

Gunawan, Imam, Metode Penelitian Kualitatif Teori dan Praktek, (Jakarta: Bumi Aksara, 2013).

Henry Subiakto dan Rachmah Ida, Komunikasi Politik, Media, dan Demokrasi, (Jakarta: Kencana Prenada Media Group, 2012).

Huntington dan Joan Nelson, Partisipasi Politik Perempuan di Negara Berkembang, (Jakarta: Rineka Cipta, 1990).

Jurnal Perempuan, Hambatan Umum Kiprah Perempuan di Politik, dalam http://www.jurnalperempuan.org/ha mbatan-umum-perempuan-dipolitik.html

Komposisi Kursi DPRD DKI Jakarta Periode 2019-2024, https://republika.co.id/berita/ infografis/nasionalinfografis $/ 19 / 08 / 30 / p x 1 \mathrm{pkd} 409-$ komposisi-kursi-dprd-dki-jakartaperiode-20192024

Muhammad Zamroni, Perempuan dalam Kajian Komunikasi Politik dan Gender, Jurnal Dakwah, Vol. XIV, No.1, 2013.

Nuri Suseno, Perempuan Politisi Dalam Partai Politik Pemilu 2014: Keterwakilan Deskriptif dan Substantif, dalam Jurnal Perempuan, Vol. 19 No. 2, Mei 2014.

Perempuan Jangan Takut Masuk Ranah Politik, dalam

https://joglosemar.co/2013/11/ perempuan-jangan-takut-masuk-ranahpolitik.html

Pernyataan Titi Anggaraini, Di Indonesia, Butuh 44 Tahun Wujudkan Keseimbangan Gender di Parlemen, dalam

https://nasional.sindonews.com/read /349658/12/di-indonesia-butuh-44tahun-wujudkan-keseimbangangender-di-parlemen-1614510177,

Rakhmat, Jalaludin, Metode Penelitian Komunikatif, (Bandung: Remaja Rosda Karya, 2000).

Resta Konitiarani, Ahmad Zuber, Upaya PDIP (Partai Demokrasi Indonesia Perjuangan) Dalam Memenuhi Kuota Calon Legislatif Perempuan (Studi Kasus Penetapan Caleg Perempuan Pada Pemilihan Umum Legislatif Tahun 2014 Di Dewan Pimpinan Cabang Pdip (Partai Demokrasi Indonesia Perjuangan) Kota Surakarta), https://jurnal.uns.ac.id/dilema/article $\angle$ view/11236/pdf (diakses 24 Januari 2021)

Richard West dan Lynn Turner, Introduction Communication Theory, (New York: McGraw-Hill, 2007).

Simabura, Charles, Alasan Walikota DKI Jakarta Tidak Dipilih Secara Langsung, https://www.hukumonline.com/klinik /detail/ulasan/lt5cd5441ad8b65/alasa n-walikota-dki-jakarta-tidak-dipilihsecara-langsung/

Situs Resmi PDIP, AD/ART, https://pdiperjuangan.id/

Profil Anggota DPRD DKI Jakarta Periode 2019-2024, 
http://statistik.jakarta.go.id/profilanggota-dprd-dki-jakarta-periode2019-2024/

Ubaedillah, A., Pancasila, Demokrasi,\& Pencegahan Korupsi, Jakarta: Prenadamedia Group, 2015).

Undang-Undang Republik Indonesia Nomor 7 Tahun 2017 tentang Pemilihan Umum.
Yogi Maulana Malik, Analisis Peran Perempuan Dalam Partai Politik Di Dewan Pimpinan Cabang Partai Demokrasi Indonesia Perjuangan (Dpc Pdi P) Kota Cirebon, https://media.neliti.com/media/publi cations/104625-ID-analisis-peranperempuan-dalam-partai-po.pdf 